\title{
The Regional Comprehensive Economic Partnership (RCEP) Without Indian Participation: Can It Work as a Mega FTA? ${ }^{1}$
}

\author{
S.C. Park
}

Sang Chul Park - Professor at Graduate School of Knowledge based Technology and Energy, Korea Polytechnic University; 2121 Jeongwang-Dong, Siheung-City, Kyonggi-Do, 429-793, Korea; E-mail: scpark@kpu.ac.kr

\begin{abstract}
There is no doubt that global trade has contributed to rapid global economic growth over the last five decades. However, trade growth slowed after the global financial crisis; while it started to recover several years after the crisis, it has again declined since 2017 due to the trade conflict between the U.S. and China, as well as other major trade partners such as the European Union (EU), Japan and Korea. The Trump administration regarded the World Trade Organization (WTO) as acting contrary to U.S. economic interests and tried to limit its arbitration function to trade negotiations and conflicts occurring between corporations rather than states. Despite the U.S.' attempt to weaken the WTO's functions, the rest of the world has tried to restore the WTO's role in free trade and multilateralism. To overcome U.S. unilateralism, many major economies have established mega free trade agreements (FTAs) such as the EU-Japan FTA, the Comprehensive and Progressive Agreement for Trans-Pacific Partnership (CPTPP) and the Regional Comprehensive Economic Partnership (RCEP). The 15 states in the RCEP agreed to complete it in 2020, signing without the participation of India - the third largest economy in Asia - although it had been part of the negotiations since 2011. Despite the absence of India, the RCEP will be the largest mega FTA in the world, covering over 30\% of global gross domestic product (GDP), and contributing to strengthened regional economic integration and growth. This article explores whether the RCEP can function properly in the absence of India and examines why India decided not to participate. Furthermore, it investigates and analyzes how the RCEP will develop without Indian participation. Last, it discusses how to set the relationship as a competitor with the CPTPP given the overlapping memberships of participating states.
\end{abstract}

Key words: Global trade; mega FTA; economic growth; regional economic integration

For citation: Park S.C. (2021). The Regional Comprehensive Economic Partnership (RCEP) Without Indian Participation: Can It Work as a Mega FTA? International Organisations Research Journal, vol. 16, no 2, pp. 157-182 (in English). DOI: 10.17323/1996-7845-2021-02-08

\section{Introduction}

It is no doubt that the global financial crisis (GFC) in 2008 escalated existing anti- globalization sentiments and created views of opposition in liberalized trade resulting from the neoliberalism. Under this condition, many countries have attempted to curtail imports and impose other restrictions on trade that has caused a de-globalization process. As a result, the global trade growth has slowed down since the Trump Administration. In 2018, the growth in the volume of world trade (goods and services) reached only 3.2 percent and the world economic growth accounted for 3.1 percent in the same year. Over six decades, the trade growth rate use

${ }^{1}$ The editorial board received the article in January 2021. 
to be double higher than the economic growth in the global economy. It means that the role of trade in the global economic growth has been limited due to protectionism. In 2020, the world economy is experiencing COVID-19 pandemic that could reduce the world trade volume in merchandise from 13 percent to 32 percent given the forecast of World Trade Organization (WTO) [World Bank, 2020a; WTO, 2020].

Under such a protectionism sentiment, 15 Regional Comprehensive Economic Partnership (RCEP) member nations agreed a mega FTA without the Indian participation in Nov. 2019 and tried to persuade India to participate in the RCEP continuously under the COVID-19 pandemic period in 2020. The Asia Pacific region has become the common ground for mega FTAs that are on the process to build the RCEP led by ASEAN officially, but practically by China and Comprehensive and Progressive Trans Pacific Partnership (CPTPP) led by Japan due to the withdrawal of the U.S. from Trans Pacific Partnership (TPP) in 2017. China has negotiated the RCEP with ten ASEAN member nations and six nations with which ASEAN have existing trade agreements. These nations are Australia, China, India, Japan, Korea, and New Zealand. The ambition of the RCEP is to promote regional economic integration in East Asia in particular. Among 16 nations in the RCEP, seven nations participate in the CPTPP as well. The CPTPP aims to rebalance of the U.S. and Japanese political and economic interests against Chinese emerging in the region as a part of global strategies. It means that the CPTPP is still open to the U.S. if she is ready to join it.

The RCEP targeted to be completed in 2020, and China pushed hard to complete it because it has already announced to protect the free trade mechanism based on globalization in World Economic Forum in 2017, while the CPTPP faced turbulence after the Trump government announced its pull out from the TPP in Jan. 2017 although 12 member nations agreed with the TPP in Oct. 2016. China regards the RCEP as an opportunity to expand the free trade system in the Asia Pacific region and plans to build Asia Pacific Free Trade Agreement (APFTA) in the near future that includes the South American countries such as Chile, Mexico, Peru etc. [Graceffo, 2017; Park, 2018].

After a long negotiation process for the RCEP since 2012, 15 member nations finally reached the agreement in the end of 2019, but unfortunately without the Indian participation that was rather unexpected and at the same time expected if you look at the industrial structure in all member nations. India as the $3^{\text {rd }}$ largest economy in East Asia can play important roles in the RCEP. It is still questionable whether or not India joins the RCEP as like the U.S. to the CPTPP although their doors are still open. It means that India regards the RCEP not as a springboard to develop its national economy continuously, but as a mechanism for opening its market more than ever.

This paper argues what are Chinese strategies and reasons to push the RCEP and discusses roles of the RCEP in East Asia and the Asia Pacific region. Furthermore, it analyzes the reasons why India did not participate in the RCEP and whether there are still possibilities for India to join it. Last, but not least, it focuses whether or not the RCEP can function properly without the Indian participation or vice versa. In order to answer these research questions, various methods such as critical analysis of the literature, inference, and qualitative analysis based on statistical data are employed.

\section{Theoretical Debates on Economic Integration}

The notion of international and regional economic integration claims that economic integration is the process of removing progressively discriminations taking place at the national level. It means the abolition of discrimination between economic actors. Economic integration is the creation of the most desirable structure of international economy that removes all artifi- 
cial hindrances to the optimal operation and introduces all desirable elements of coordination. Countries interested in the process start from free trade agreements (FTAs) that is rather a simple form and the first step for the further economic integration. Later they progress through more advanced forms in terms of customs union, common market, and economic union. After these processes, an economic union can be a political union, but most scholars agree that there are no examples of political union. In practice, the sequence of process in economic integration does not always occur because the achievement of the final stage needs a high level of political integration that causes a loss of sovereignty in the member nations [Tinbergen, 1954; Balassa, 1961; Hosny; 2013; Park, Pasierbiak, 2018].

Countries participating in the economic integration must consider benefits and costs of the process that are not only based on economic, but also political and social perspectives. In economic terms, benefits must be larger than costs. However, it is also worth to emphasize that an efficient integration process requires a fair division of political and social benefits and costs between member nations. Based on the economic sphere, benefits of economic integration are mainly a growth of trade turnover among the member nations in the short run, while they rely on increasing production and improving productivity in the long run that result in the economic growth in the member nations. During implementing the integration process, a reduction of barriers enables wider openness among member nations for foreign companies that make increase competition and efficiency. Furthermore, a larger market attracts new business activities including investment, and existing companies make greater effort to compete with foreign companies. It increases productivity and leads to a better allocation of resources and technology transfer that generates a positive effect on consumption, wealth, and quality of life among the member nations [Molle, 1990; Siddique, 2007].

Economic integration theories discuss benefits and costs of regional economic integration that explain the effects of integration. The traditional economic group presents a model for free trade and estimated welfare gains reducing or eliminating trade barriers that is a static approach based on the short run. By contrary, the dynamic economic group takes into account ever changing economic conditions so that free trade benefits society through gains in overall quality and variety and strengthen industrial competitiveness through technology transfer and innovation. It is a dynamic approach based on the long run [Bhagwati, Panagariya, 1996; Krugman, 1979; Krugman, Obstfeld, 2009; Broda, Weinstein, 2006].

Later, scholars developed further new regionalism based on FTAs from a cross regional perspective that represents a new form of economic integration in $21^{\text {st }}$ century. They argue that cross regional trade agreements have been the new trend of the current international trade systems such as the Trans Pacific Partnership (TPP), the Transatlantic Trade and Investment Partnership (TTIP), the Regional Comprehensive Economic Partnership (RCEP) etc. The emergence of mega FTAs is not a random phenomenon, but part of the evolution of the $21^{\text {st }}$ century regionalism that is closely linked to the $21^{\text {st }}$ century trade in goods, services, parts and components. In fact, the mega FTAs have resulted from preferential trade agreements (PTAs) and regional trade agreements (RTAs) because multilateral trade negotiations guided by the WTO did not make any progress. As a result, PTAs, RTAs, and mega FTAs have filled the gap in global governance and reshape the world economic order. The mega FTAs, particularly in Asia are shaped by the dominant political interests in its member states and by the particular character of economic interdependence in the region [Velut et al., 2018; Kimura, Chen, 2016; Ravenhill, 2016].

This study adopts a dynamic model rather than a static model because the former can explain the long term benefits of free trade more precisely than the latter. Moreover, the dynamic model based on long term efficiency gains and economic growth can be emphasized in order to explore approaches of the RCEP expecting a further economic growth higher than in any 
other region in the world. The dynamic model also advocates the free trade system operated by the WTO rules. However, the turbulence in the world trade mainly caused by the U.S.-China trade conflict has recently made the WTO stop working properly. Additionally, the WTO has only focused on multilateral trade agreements that used to take a long time. As a result, many countries across the world have to look after other alternatives such as bilateral FTAs, regional trade agreements (RTAs) and mega FTAs such as the RCEP and the CPTPP. Therefore, it is also wise to adopt new regionalism as a theoretical background along with the dynamic model.

\section{RCEP as the largest Mega FTA}

\section{Development path and current issues}

East Asian countries discussed the desirability and feasibility of Asian economic cooperation several years since the 2000s. After a long discussion, East Asian countries led by the ASEAN member countries decided to establish the RCEP and started to negotiate in 2013. The nations participating in the RCEP negotiations are the ten ASEAN member nations and six other nations such as Korea, China, Japan, India, Australia, and New Zealand.

East Asia has not established a region wide FTA due to different opinions among East Asian economies about creating a region wide FTA. It was a long process to agree to the RCEP. Regional economic cooperation in East Asia began to intensify in order to deal with Asian Financial Crisis (AFC) in 1997 as the first ASEAN+3 (China, Japan and Korea) Summit Meeting was held in 1998. In the summit, Korea proposed to set up East Asia Vision Group (EAVG) in order to overcome economic and financial problems collectively in the region. Moreover, the EAVG studied a long term vision for economic cooperation in the region. The expert group developed the idea of East Asia Free Trade Area (EAFTA) in 2002 and proposed ASEAN+3 economic ministers that the EAFTA needs to negotiate among ASEAN countries first, and a further membership can be open to other East Asian economies. Unfortunately, however, this proposal was not accepted due to various different national interests in 2006. The economic rationale of EAFTA was based on building highly developed production networks and supply chains among ASEAN+3 nations and harmonizing rules of origins among these countries. If these plans are realized, tangible economic benefits could be generated. Furthermore, the ASEAN+3 cooperation is able to develop the most feasible regional framework in East Asia [Urata, 2013; JEG, 2009; ASEAN Secretariat, 2009; Kawai, Wignaraja, 2011].

Compared with the Korean approach to ASEAN+3, Japan proposed Comprehensive Economic Partnership in East Asia (CEPEA) at the ASEAN+6 economic ministers' meeting in 2006. The Japanese proposal was an agreement of the region wide FTA covering ASEAN+6 member nations. These 16 nations were also the member nations of the East Asia Summit that began in 2005. Japan's economic rationale to set up the CEPEA was that the economic advantage of the CEPEA could be larger than that of the EAFTA because the incorporation of resource rich Australia and rapidly growing India could generate economic growth of East Asia as a whole. However, the reason why Japan suggested the CEPEA was that Japan tried to play a role in the leadership for setting up a regional institution because China took the initiative in the EAFTA discussions. By competing with each other between China and Japan to take a leadership in the establishment of the region wide FTA under the EAFTA and the CEPEA, China speeded up the process of regional economic integration in East Asia when Japan decided on participating in Trans Pacific Partnership (TPP) led by the USA in 2011 [Kawai, Wignaraja, 2008; Xiao, 2015].

The Chinese motivation to establish the EAFTA was stronger than any other nations in the region because it observed increasing US influences to form a regional economic framework 
in the Asia Pacific region under the TPP. The Obama government started to take initiatives to complete the TPP in 2009. Under this circumstance, ASEAN proposed the RCEP involving ASEAN and its FTA partners in 2011 because it did not want to lose ASEAN centrality in East Asian regional economic integration. ASEAN understood that it could lose its role of leadership position in the process of economic integration in East Asia if big economic nations in the region and half of ASEAN member nations participate in the negotiation of the TPP. Additionally, ASEAN tried to maintain its centrality in the regional economic cooperation. After signing ASEAN+1 (China) FTA, ASEAN and its regional partners concerned about the Asian noodle bowl effects that became new obstacles to establish new regional production networks based on free markets in East Asia. Therefore, the RCEP has emerged as a tool to integrate ASEAN+1 FTA in order to support their common aspirations of the region. In the RCEP framework, ASEAN member nations can solve the noodle bowl effects effectively at once [Yi, 2014].

Additionally, ASEAN announced the guiding principles for the negotiations of the RCEP that include the WTO consistency, transparency, and open accession to ASEAN's FTA partners and others. Based on such principles, four ASEAN member nations such as Brunei, Malaysia, Singapore, and Vietnam participated in the TPP and later the CPTPP without the U.S. participation as well. As a result, ASEAN+6 leaders agreed to launch the negotiation of the RCEP in 2012 and to start in 2013. The RCEP was scheduled to conclude by the end of 2017, but did not meet the target and completed in Nov. 2020 without Indian participation. It targets to reassure the world of free trade commitment [ASEAN Secretariat, 2012; Urata, 2013; Hearn, Myers, 2015; Johnston, 2017] (see Fig. 1).

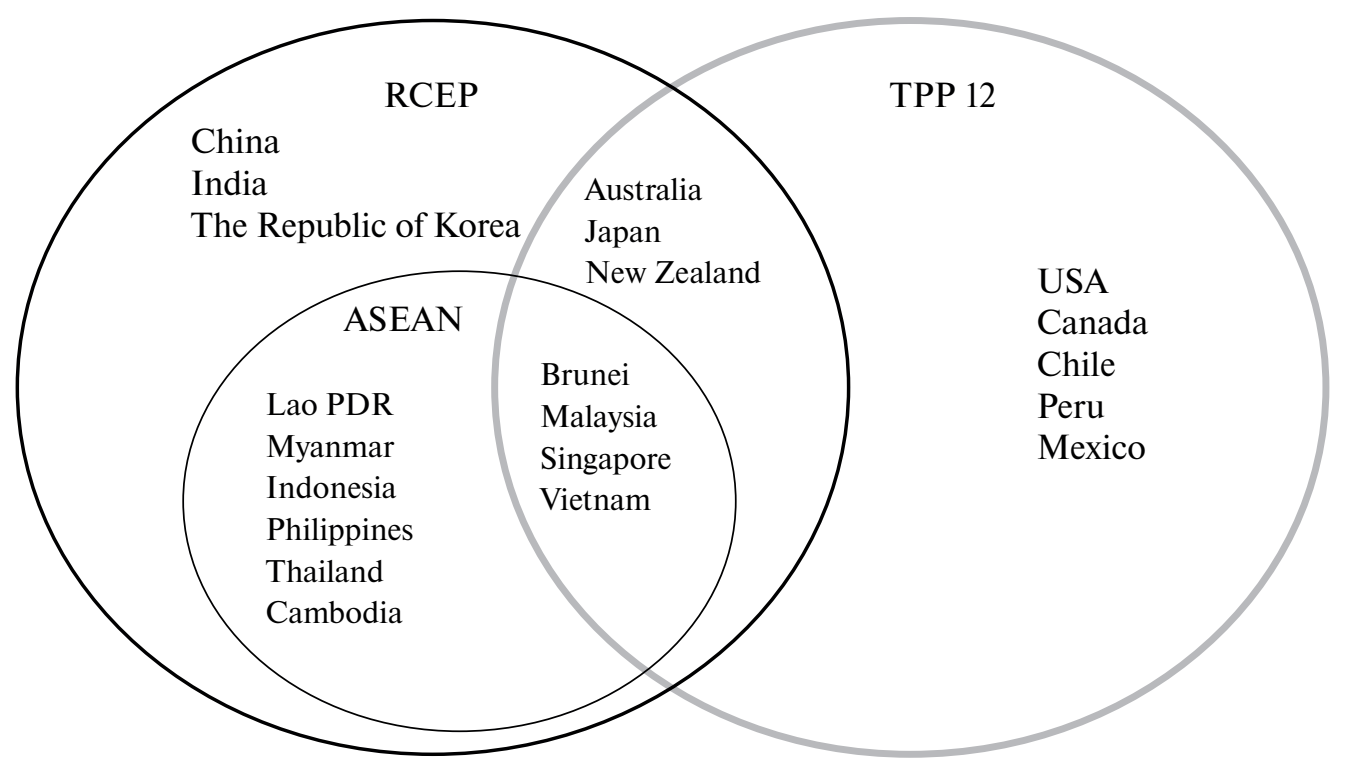

Fig. 1. RCEP and TPP Member Nations (As of 2016)

Source: [Expertise Asia, 2016].

The RCEP could be a strong rival of the TPP in the East Asian economic integration. It includes more than 3.6 billion populations, the output about 27.4 trillion US dollars, and accounts for around 33.1 percent world trade in merchandize in 2018. Its GDP accounted for $31.9 \%$, and the total trade volume was 13.1 trillion US dollars in the same year. It is no doubt that the RCEP could create the world largest trading bloc, if it is successfully concluded. It 
could provide major implication for the global economy such as spread of global production networks, reducing inefficiencies of multiple Asian FTAs such as noodle bowl effects, strengthening East Asian economic integration etc. [Suh, 2014; World Bank, 2016; World Integrated Trade Solution, n. d.].

From 2014 to 2018, the RCEP changed its global share in terms of population, GDP, and trade volume. Firstly, the global share of population declined from 49 percent to 47.4 percent during the same period. Secondly, the GDP of the RCEP increased from 29 percent to 31.9 percent. Finally, its trade volume in merchandize declined from 35 percent to 31.09 percent. It means that the share of population declined due to increasing income level rapidly and its share of GDP increased continuously based on a high economic growth in the region. Last, but not least, its share of trade volume in merchandize was shrunken because its service sectors increased that upgrades the whole industrial structure and the economic level [World Bank, 2020] (see Fig. 2).

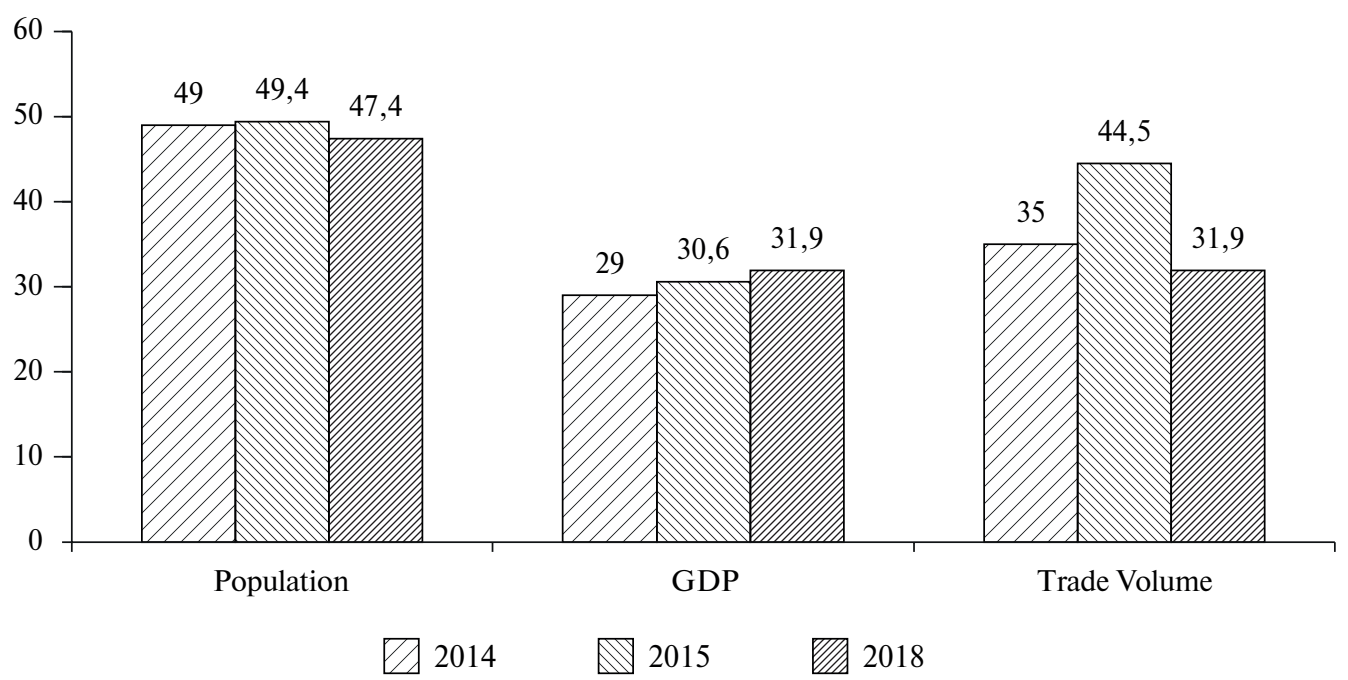

Fig. 2. RCEP's Share of World in Population, GDP, and Trade (\%)

Source: [WTO, World Trade Statistics, 2015; 2016; 2019; The World Bank, 2020a].

The RCEP needs a strong leadership that is absolutely necessary to conclude the agreement successfully in 2020 and ratify it in all member nations in the near future. The leadership must be officially based on ASEAN centrality because its role is regarded as impartial, but it has been influenced by China heavily in recent years. In fact, the RCEP is a tool for rising China in the region. ASEAN, Korea, and Japan are concerned that China will eventually dominate East Asia through a China-led East Asia Economic Community. Therefore, some countries such as Japan, Myanmar, the Philippine, Vietnam have actively tried to balance between China and the U.S. in order to hedge China's possible threat. Unfortunately, however, the Trump government withdraws from the TPP due to the America First policy. It provided China to take a strategic advantage for the RCEP in the region. After the U.S. presidential election in 2020, Biden was elected. The Biden administration declared to restore its traditional policy lines such as multilateralism based on allies supports and cooperation in 2021. Therefore, it may be possible that the U.S. rejoin the TPP during the Biden's term. If it is realized, the newly formed TPP led by the U.S. would change the competitive role between the RCEP and the TPP substantially in the region [Suh, 2014; Shott, 2017; Mueller, 2019; Akimoto, 2021]. 
However, the TPP without the U.S. leadership leaves China as the leader of large scale regional economic integration with the RCEP that plays the role of main pillar. Moreover, the RCEP will probably be more open to new members in the Asia Pacific region. China foresees Chile and Peru's participation in the RCEP and emphasizes its intention to keep its scheme open to any possible member nations. As a result, the RCEP may enhance the regional and global roles of China that potentially contributes to creating bilateral rivalry with the USA. Among the major member nations in the RCEP, their priorities are very diverse. China enhances its intention to make the RCEP as a basis of trade rules in the Asia Pacific region, while Japan focuses on providing a high level of liberalization comparable to that of the TPP. India is keen to provide liberalization of trade in goods more than in services and investment, while Korea stands for high level of liberalization in trade and investment. Despite wide and different national interests among member nations, they have agreed to discuss goods, services, and investments as one package, primarily at India's insistence. Prospects of the RCEP seem to be positive because compromises leading to agreement are feasible. 16 member nations have accumulated their experiences by completing ASEAN+1 FTA, ASEAN+3 FTA, and other bilateral FTAs in the region. In Nov. 2019, 15 member nations in the RCEP without India's participation had finally agreed on all 20 chapters and essentially all their market access issues and decided to proceed with legal processes. The RCEP signed in Nov. 2020. China can use it as a tool to set up trade rules in the region [Kumar, Charlton, 2017; Basu Das, 2017; Chaisse, 2020].

\section{RCEP and the three major economies' strategies}

In the RCEP, major economies such as China, India, and Japan do have their own national interests that are rather very diverse. Among these three economies, China already launched FTA with ASEAN in 2001 that is called as ASEAN Plus One (ASEAN+1). Later, Japan and Korea participated in ASEAN Plus Three (ASEAN+3) in 2010. In fact, India was a latecomer negotiating to become a member of the RCEP in 2013.

China started the regional FTA with ASEAN as a whole and tried to integrate its economy with East Asian countries in order to expand their markets on the one hand, and to create its regional supply chains on the other. In order to meet the target, China preferred to adopt the ASEAN+3 framework initiated by Korea, while Japan proposed the ASEAN+6 framework. The disagreement between the two nations stemmed from a rival relationship in East Asia, and they focused on maximizing their national economic interests. As a result, ASEAN proposed the RCEP to assume leadership of the group and respond properly to the evolution of the trilateral FTA between China, Japan, and Korea as well as the TPP [Hamanaka, 2014; La, 2017].

Originally, East Asian regionalism was initiated by Japanese investment and transport of production in the end of the 1980s. However, since Chinese rise in the 2000s, and its surpassing the Japanese economy in 2010, China took over the economic leadership in the region and became a regional hub for trade and production that has accelerated economic integration and generated sustainable growth. In East Asia, two mega FTAs such as the RCEP and the TPP later turned to the CPTPP are competing for the leadership of the East Asian economic integration with each other. It illustrates that the U.S. and China have entered a competitive stage in the region until the U.S. maintained its leadership in the TPP [Kim, 2015; Park, Pasierbiak, 2018].

China's strategies to pursuit the RCEP are based on three fold motives. Firstly, China had to respond to the strategic repositioning of the U.S. in the Asia Pacific named as Asian Pivot Policy of the Obama government in 2008. China's rise in the 2000s created deepening East Asian economic cooperation and at the same time caused strategic vigilances among Southeast Asian countries. The U.S. legitimated its new regional presence in terms of rebalancing in the Asia Pacific and tried its strategic engagement in the region as a facilitator for the East Asia's 
integration into the global order based on the establishment of the TPP [Clinton, 2011; The White House, 2012].

Secondly, Chinese domestic debates relating to the renewed identities and its regional and global roles in changing self-image as an economic superpower known as G2 influenced economic and foreign policies as an intervening factor. It focuses on strengthening the regional and global trade order particularly in the Asia Pacific region that is based on China's FTA policies for the economic diplomacy [Jiang, 2010].

Lastly, but not least China has promoted the RCEP as a part of the outcome of the strategic thinking on the regional leadership in the face of the U.S. rebalance in the region. It regards the RCEP as a tool for regional economic integration with neighboring countries in a structural dimension of rivalry with the U.S. China also thinks that close relations with countries in the region play a significant role in selecting and determining the path of the RCEP negotiation and agreement in which direct interactions between regional and Chinese officials take place. It could contribute to increasing mutual economic and political interests in the region as well as China's interaction with East Asian neighboring countries [Kim, 2015].

Japan's strategy regarding the RCEP was to use China to improve its TPP negotiation position vis-à-vis the U.S. China and Japan disagreed how to set agenda in the RCEP. The former mainly wanted to set the RCEP for the trade in goods with ASEAN+3, while the latter approached a comprehensive trade in goods and services including investment and intellectual property rights (IPRs) with ASEAN+6. After Japan secured a seat at the TPP negotiation table backed by the U.S. support, it resumed its agenda setting vis-à-vis China and the RCEP negotiations. As a result, Japan was able to enforce China to include investment and IPRs issues in the RCEP with violations subject to dispute settlement. The core point of Japanese strategy for the RCEP is to check and balance the expansion of Chinese influences in the Asia Pacific region by using the U.S. economic and political power in the TPP and forming alliances with Australia and India participating in the RCEP. Overall, it focuses on checking and controlling the Chinese expansion in the region with the participation in the two mega FTAs, while cooperating with its close allies such as Australia, India, and the U.S. at once [Hamanaka, 2014; Terada, 2013].

India had been a part of the RCEP negotiating process since the Japanese idea of ASE$\mathrm{AN}+6$ was accepted in the RCEP. Its strategy for the RCEP is based on the three pillars; Firstly, India focuses on increasing its presence in Southeast and East Asian markets. Secondly, it tries to build a closer relationship with ASEAN as an institution based on geographical proximity, historic and cultural heritage between the two parties. Lastly, it is keen to increase connectivity with Northeast Asia and Oceania that could bring investment, high technology, and raw materials to India [Panda, 2014; Palit, 2019] (see table 1).

Table 1. Strategies of China, Japan, and India for the RCEP

\begin{tabular}{|c|c|c|c|}
\hline & China & Japan & India \\
\hline Strategies & $\begin{array}{l}\text { 1) Responding to the strategic } \\
\text { repositioning of the U.S. in the } \\
\text { Asia and Pacific region } \\
\text { 2) Renewing its identity as an } \\
\text { economic superpower and } \\
\text { influencing regional and global } \\
\text { trade order } \\
\text { 3) Playing regional leadership in } \\
\text { the region }\end{array}$ & $\begin{array}{l}\text { 1) Improving its TPP negoti- } \\
\text { ating position } \\
\text { 2) Initiating agenda setting } \\
\text { such as investment and } \\
\text { IPRs } \\
\text { 3) Checking and controlling } \\
\text { Chinese expansion in the } \\
\text { region by using alliances' } \\
\text { power }\end{array}$ & $\begin{array}{l}\text { 1) Focusing on market } \\
\text { expansion } \\
\text { 2) Building closer rela- } \\
\text { tions with ASEAN } \\
\text { 3) Increasing connectiv- } \\
\text { ity with Northeast Asia } \\
\text { and Oceania }\end{array}$ \\
\hline
\end{tabular}

Source: Adapted by the author. 


\section{India's withdrawal from the RCEP}

The RCEP negotiations concluded at the $3^{\text {rd }}$ ASEAN Summit in Bangkok in Nov. 2019 after $29^{\text {th }}$ round of negotiations since May 2013. The 15 RCEP member nations without the Indian participation agreed to commence preparation of the legal text of the agreement composed of 20 chapters for signing in 2020. India was the only member country to reject the agreement due to significant outstanding issues that are mostly confront by domestic economic conditions.

Domestic pressures made Prime Minister Modi to withdraw India from the RCEP although it had participated in the negotiations actively from the beginning in 2013. Therefore, India's decision surprised other member nations at the last negotiation. It indicates that disengagement with other trade partners or blocs become a prominent direction of India's trade policy because domestic protectionist views and interests are successfully able to undermine outward oriented economic policy. In India, the RCEP has never been supported by the business and economic groups because it is regarded as de facto FTA with China notwithstanding the presence of other major economies such as ASEAN, Japan and Korea in the group. The trade with China in the RCEP means India that Chinese imports increase even more rapidly because the RCEP grants China preferential access comprehensively. It could increase Indian trade deficit with China even larger than now that is the main concerns of Indian perspectives [Palit, 2019].

India suggested a three tiered approach in the RCEP negotiations on trade in merchandize goods. It involves tariff concessions or elimination on 80 percent lines for ASEAN countries, 62.5 percent for Japan and Korea, and 42.5 percent for Australia, China, and New Zealand. Despite the lowest level of tariff elimination for China in the RCEP member nations, the trade deficit with China increased to USD 53.6 billion in 2018 that was 62 percent of the total trade deficit in the same year. India's trade deficit accounted for USD 87.1 billion in 2018. Moreover, a deep consternation over the unbalanced trade between China and India has existed. Indian government agencies and industries have recognized the India's dependence on China's imports and Indian's inability to develop a broad industrial manufacturing base compared with China. These resulted in the limitation of the RCEP's acceptability from the beginning because India fears more Chinese imports flooding to the Indian economy. Additionally, a traditional geo-political discomfort toward China also plays a role in avoiding the RCEP agreement among the domestic interest groups [Seshadri, 2017; Palit, 2019; The World Bank, 2020b].

India is the third largest economy in the RCEP after China and Japan. Its GDP accounted for USD 2.7 trillion in 2018 that was c.a. 10 percent of the total output in the RCEP. Indian economy was more or less the same size of the whole ASEAN member nations. Its trade volume in merchandize goods reached to USD 1.2 trillion in the same year that was the fifth largest volume in the RCEP member nations. The trade volume was lower than the Korean trade volume because India does not pursuit outward trade policy for its economic development strategy. Despite the withdrawal of India, the RCEP will not be affected seriously because of its limited GDP share in the total share of the RCEP member nations. Additionally, the other mega FTA in the region, the CPTPP has also been shrunken due to the U.S. withdrawal. The U.S. GDP accounted for c.a. 65 percent of the TPP's output. Therefore, the RCEP will still remain the largest mega FTA after the India's withdrawal and play a dominant role in the Asia Pacific region [The World Bank, 2020; Park, 2017] (see Table 2, Fig. 3). 
Table 2. GDP and Trade Volume of Merchandize Goods in the RCEP Member Nations (As of 2018)

\begin{tabular}{|l|c|c|}
\hline \multicolumn{1}{|c|}{ Member Nations } & GDP (USD Trillion) & Trade Volume (USD Trillion) \\
\hline ASEAN & 2.9 & 2.8 \\
\hline China & 13.6 & 5.2 \\
\hline Japan & 5.0 & 1.9 \\
\hline India & 2.7 & 1.2 \\
\hline South Korea & 1.6 & 1.3 \\
\hline Australia & 1.4 & 0.6 \\
\hline New Zealand & 0.2 & 0.1 \\
\hline Total & $\mathbf{2 7 . 4}$ & $\mathbf{1 3 . 1}$ \\
\hline
\end{tabular}

Source: [The World Bank, 2020b].

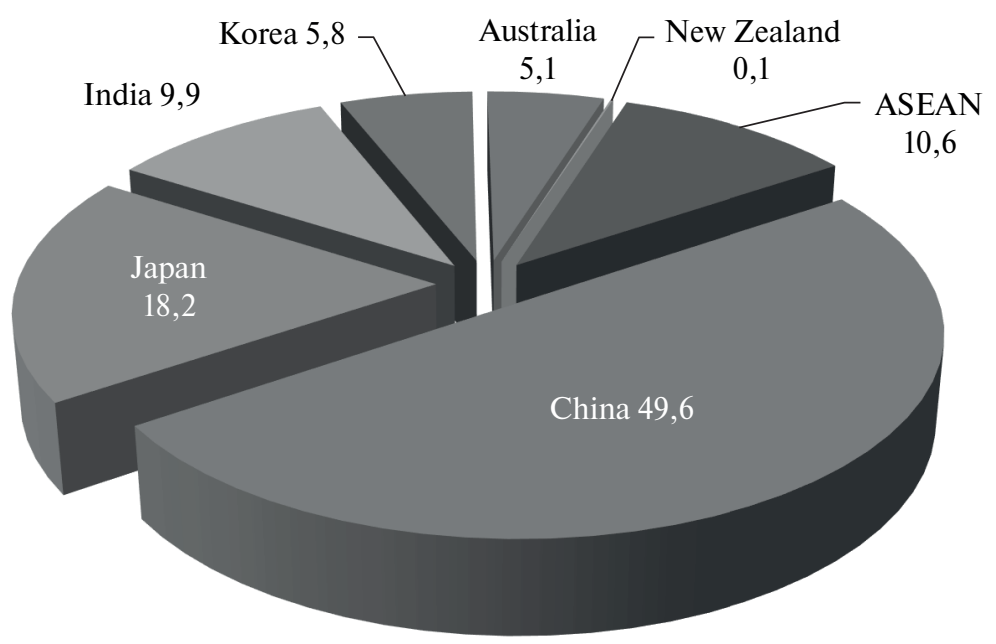

Fig. 3. Share of GDP in the RCEP Member Nations (As of 2018, \%)

Source: [The World Bank, 2020b].

\section{Analysis on the RCEP and the India's Withdrawal}

\section{The RCEP and the regional economic integration in Asia}

The RCEP member nations have intensified their economic integration since the 1990s. ASEAN initiated the East Asian economic integration since its establishment in the early 1970s, and Japan took over its leadership to create the Asian Monetary Fund (AMF) in the early 1990s. However, the Japanese leadership in East Asia failed due to the U.S. pressure. After the Asian Financial Crisis (AFC) in 1997, Korea suggested a joint financial cooperation between ASEAN 
and Northeast Asian countries that resulted in the Chiang Mai Initiative (CMI) in 2001. The CMI was the starting point for East Asian countries to cooperate with one another and support them jointly in the financial market that has played a significant role in integrating the regional economy. In fact, the regional production network (RPN) was already created by the Japanese industries in the 1990s, and Korea also participated in the regional supply chain (RSC). Finally, China has become a part of these since the 2000s [Park, Pasierbiak, 2018].

The economic cooperation between ASEAN+3 based on the RPN, the RSC, and the financial cooperation has contributed to increasing the regional economic integration in the region although there is no legal binding or institutions such as the European Union (EU) or the North American Free Trade Agreement (NAFTA). Despite the absence of the institutional approach, the ratio of the regional economic integration has been much higher than in the NAFTA, but slightly lower than in the EU in 2018. The regional economic integration in Asia has increased rapidly since the 1990s. It was initiated by Japan, and Korea followed. After the Chinese participation in the process of the regional economic integration based on intra- regional trade, its role as an economic leader increased rapidly since the 2000s [ADB, 2019] (see Fig. 4).

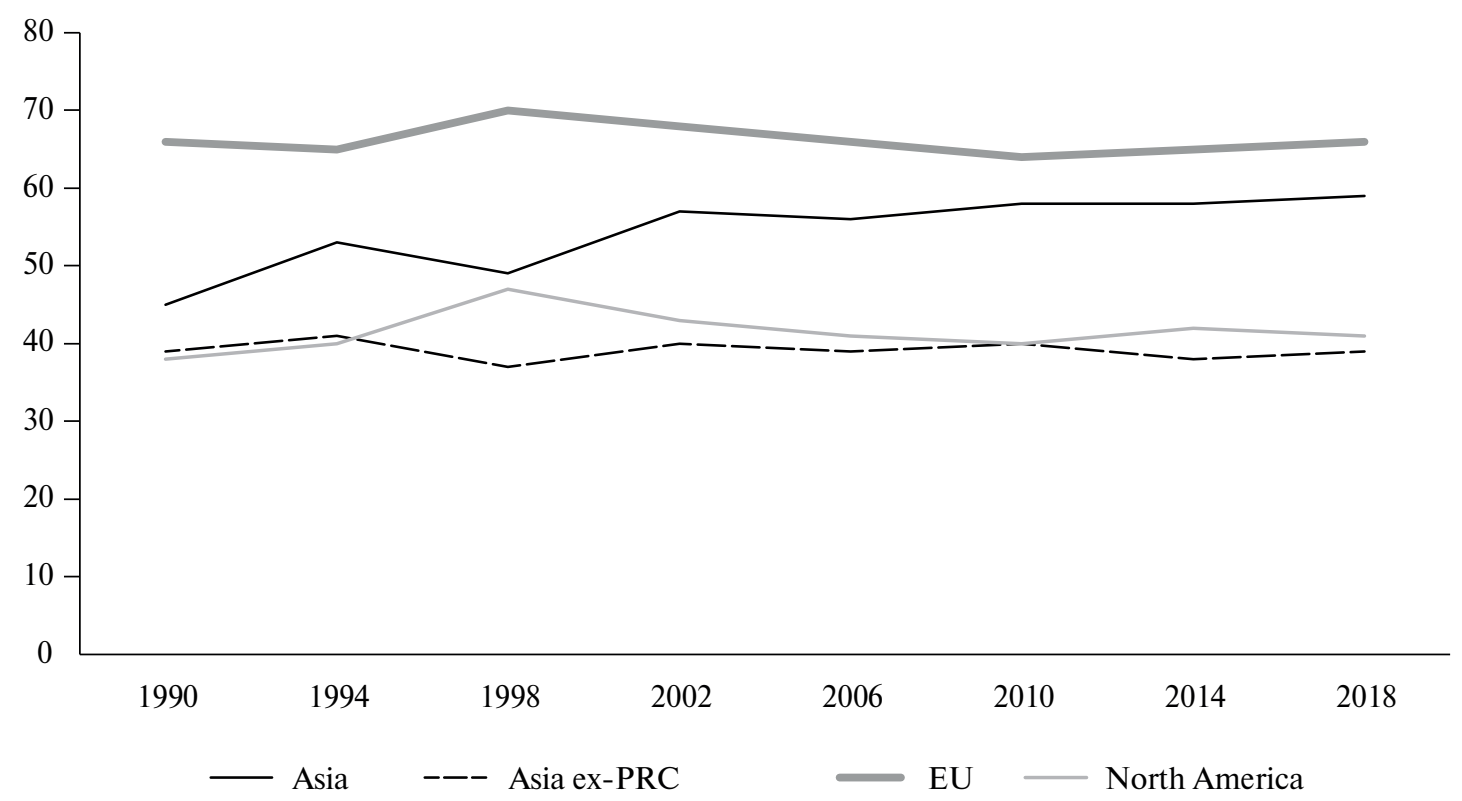

Fig. 4. Intra Regional Trade Share in Asia, the EU, and North America (As of 1990-2018, \%)

Source: Authors own adaptation based on data from ADB, 2019ADB.

The regional trade is one of the most important factors to measure the regional economic integration along with foreign direct investment (FDI). In line with the process, intraregional trade shares in Asian countries increased across all sub-regions from 2010 to 2018. Among these, the Pacific and Oceania countries increased the highest intraregional trade share with 71.7 percent in 2018. South East Asian countries followed the second highest share with 69.3 percent in the same year. The intra trade share of East Asian countries accounted for 55.5 percent as the third highest share. During the same period, Central Asia's intraregional trade share increased mostly from 28.1 percent to 33.3 percent that is 18.5 percent increase. South Asia followed from 35.4 percent to 40 percent that accounts for 13 percent increase. Overall, 
all sub-regions increased their regional intra trade share. It means that the leverage of the most of Asian sub-regional economies lay in Asia instead of the rest of the world. Even Central and South Asian economies try to catch up this trend rapidly. As a result, Asian economies are more dependent on one another than on the rest of the world in terms of the trade [ADB, 2019] (see Fig. 5).

Global FDI inflows fell in the three years raw from 2016 to 2018. It was estimated at USD 1.3 trillion in 2018 that accounted for a 13.4 percent decline from 2017. Despite the global slowdown of FDI, Asia was able to continue as the most important destination attracting 43.1 percent of the global total FDI. The FDI inflows to Asia increased 6.3 percent in 2018 compared with the amount of the FDI inflows in 2017. It means that Asia's inward FDI proved still bullish in 2018 despite the declining global trend. FDI to Asia in 2018 grew by 6.3 percent compared with 1.1 percent increase in 2017. This accounted for USD 559.7 billion that represented 43.1 percent of the global inward FDI. Asia was the largest recipient of the global inward FDI in the world. The top 10 destinations of the inward FDI in Asia were China, Hong Kong, Singapore, Australia, India, Indonesia, Vietnam, Korea, Thailand, and Japan.

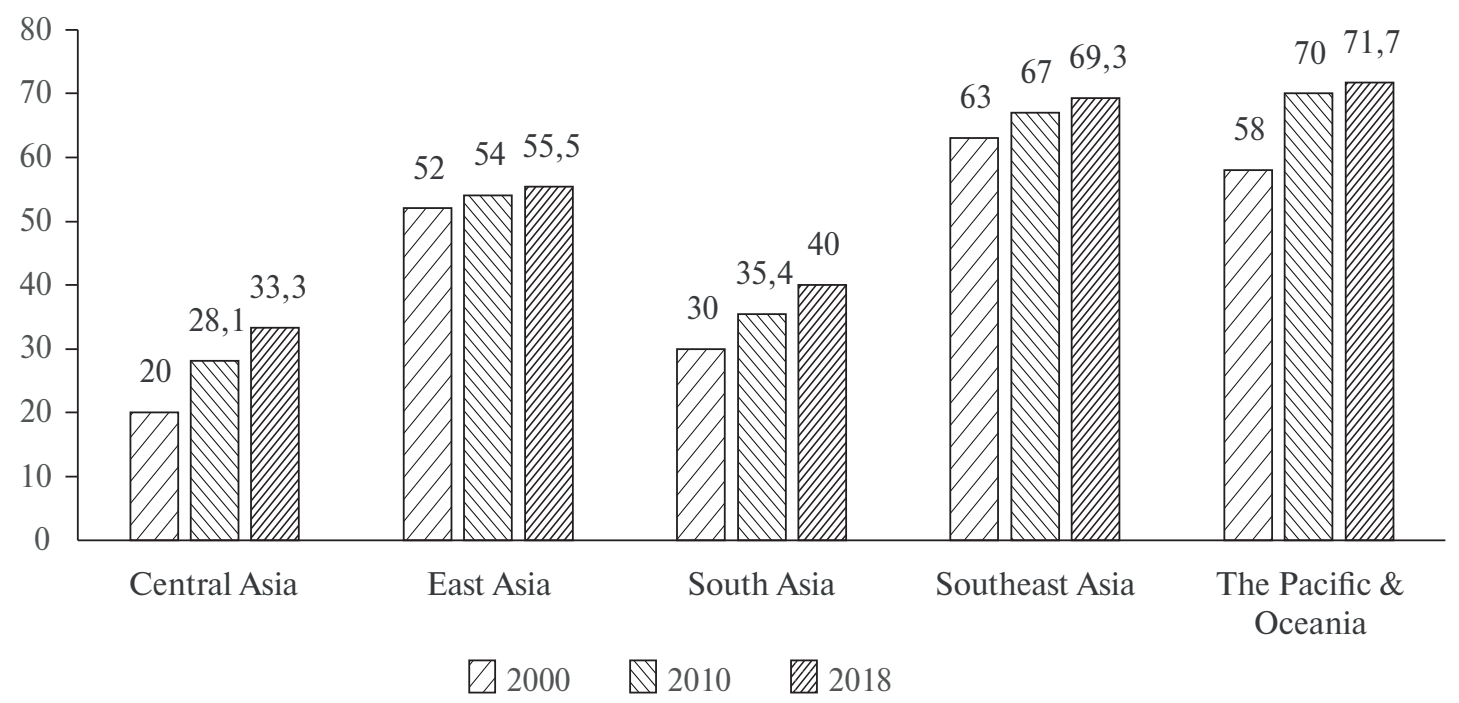

Fig. 5. Intraregional Trade shares by Asian Sub-regions (As of 2000 2018, \%)

Source: Authors own adaptation based on data from [ADB, 2019].

At the same time, intraregional inward FDI has increased since 2001. It started to decline before the global financial crisis (GFC) in 2008, but increased again after the GFC and stabilized since 2010. It fluctuated around 50 percent of the Asian total FDI from 2010 to 2018. Intraregional activities such as industrial output, trade etc. relies on investment within subregions to a high extent. In 2018, intra sub-regional investment accounted for 28.8 percent of total inward FDI to Asia. At the same time, FDI across sub-regions regained from 2015 to 2018. The share of inter sub-regional investment increased to 19.4 percent in 2018. In sum, 48.2 percent of total FDI was invested either across or within sub-regions in Asia. The rest was invested to the rest of the world. It means that Asian countries invested around 50 percent of their FDI in Asia that contributed to increasing the regional economic integration along with the trade [ADB, 2019] (see Fig. 6). 


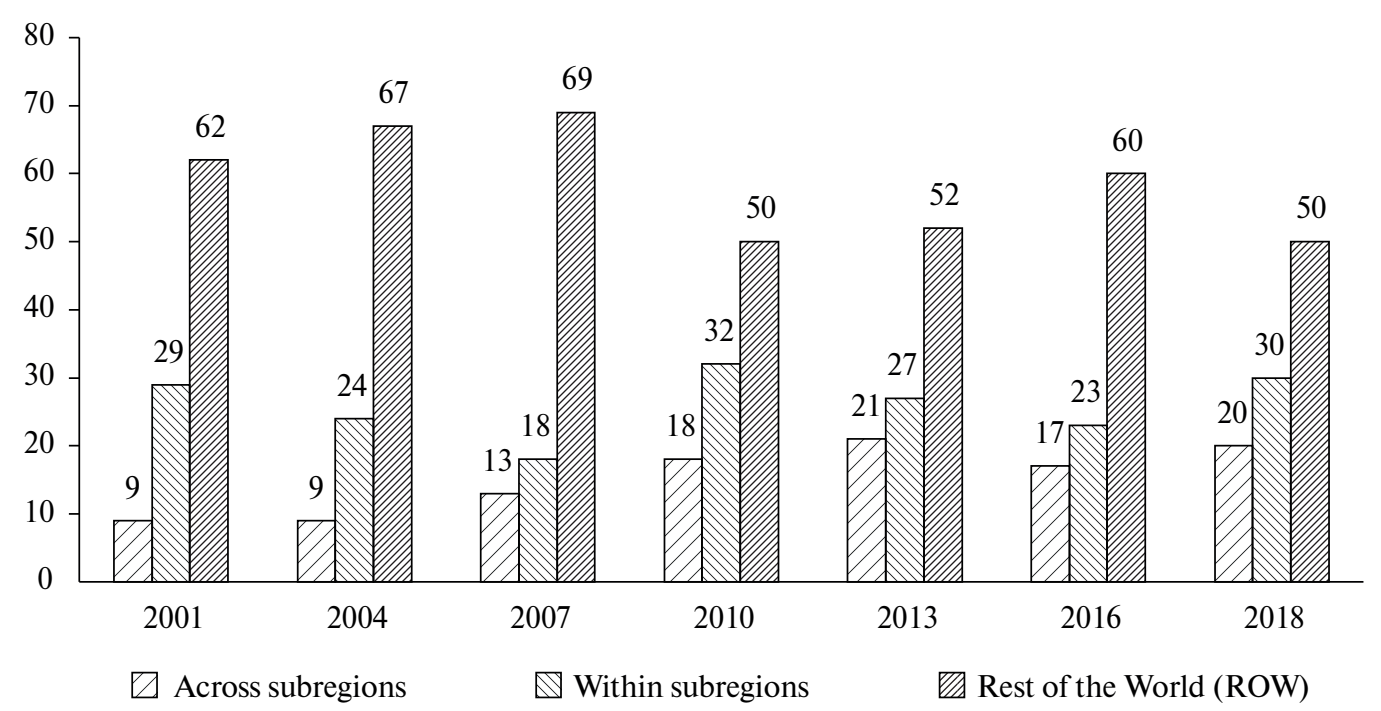

Fig. 6. Regional FDI Share in Asia (As of 2001 2018, \%)

Source: Authors own adaptation based on data from [ADB, 2019].

\section{Reasons for the India's Withdrawal from the RCEP}

It was not expected that India decided on its withdrawal from the RCEP in the $3^{\text {rd }}$ Summit Meeting in Nov. 2019. It surprised other member nations as well. However, there are several reasonable reasons why India had to withdraw its participation in the RCEP in the last minute. First of all, the Indian trade intensity with the RCEP was lowest with 24 percent in 2014, while ASEAN, Australia, and New Zealand accounted for 58.3 percent, 66.2 percent, and 57.8 percent respectively. The shares of Japan and Korea exceeded 40 percent of their global trade while Chinese trade with the RCEP accounted for 32.2 percent of its global trade in the same year. At the same time, India had the trade deficit in the intra RCEP trade with 40 percent of the total trade volume that was the highest share in the RCEP member nations. After India, Japan, China, and New Zealand followed the trade deficit. Among the RCEP member nations, ASEAN, Australia and Korea had the trade surplus in the intra RCEP trade. It means that India's position in the RCEP was the weakest compared with other member nations [Seshadri, 2017] (see Fig. 7).

Secondly, India has run a large trade deficit with the RCEP member nations. It has looked for specific protections its industry and farmers from a surge in imports. The India's trade deficit particularly with China increased from USD 44.8 billion in 2014 to USD 53.5 billion in 2018 that accounted for 50.9 percent of the India's total trade deficit with the RCEP member nations. India's trade intensity with the RCEP increased from 24 percent in 2014 to 25.5 percent in 2018 slightly that was still the lowest among the member nations. At the same time, the share of intra RCEP trade deficit also improved from 40.3 percent to 35.5 percent during the same period substantially. Generally, the Indian trade relations with the RCEP member nations became better with increasing share of exports and declining share of trade deficit in the intra RCEP trade since India participated in the RCEP negotiations in 2013. [Panda, 2019; Sarma, 2020] (see Fig. 8) 


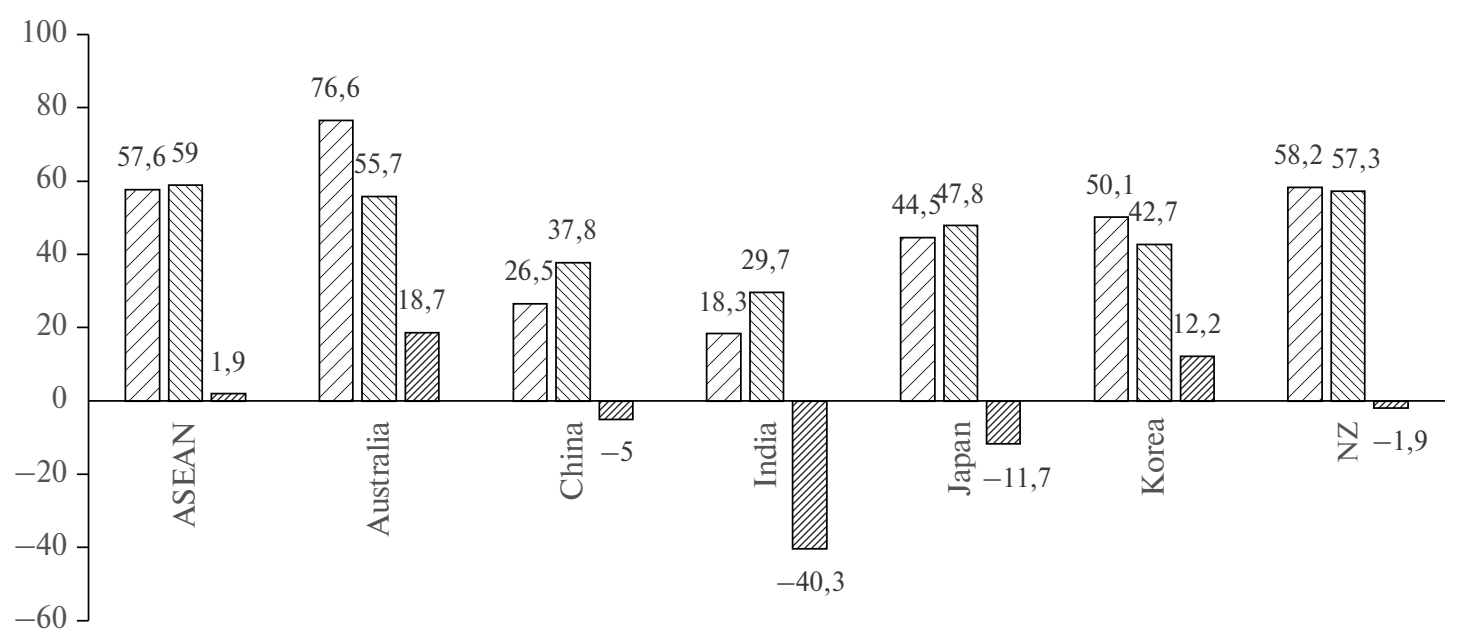

7 Share of exports to other RCEP countries vis-à-vis global exports

Share of imports from other RCEP countries vis-à-vis global imports

ZA Trade balance with RCEP countries vis-à-vis total trade

Fig. 7. Shares of Intra RCEP Trade Among the Member Nations (As of 2014, \%)

Source: [Indian Government, Department of Commerce, 2017].

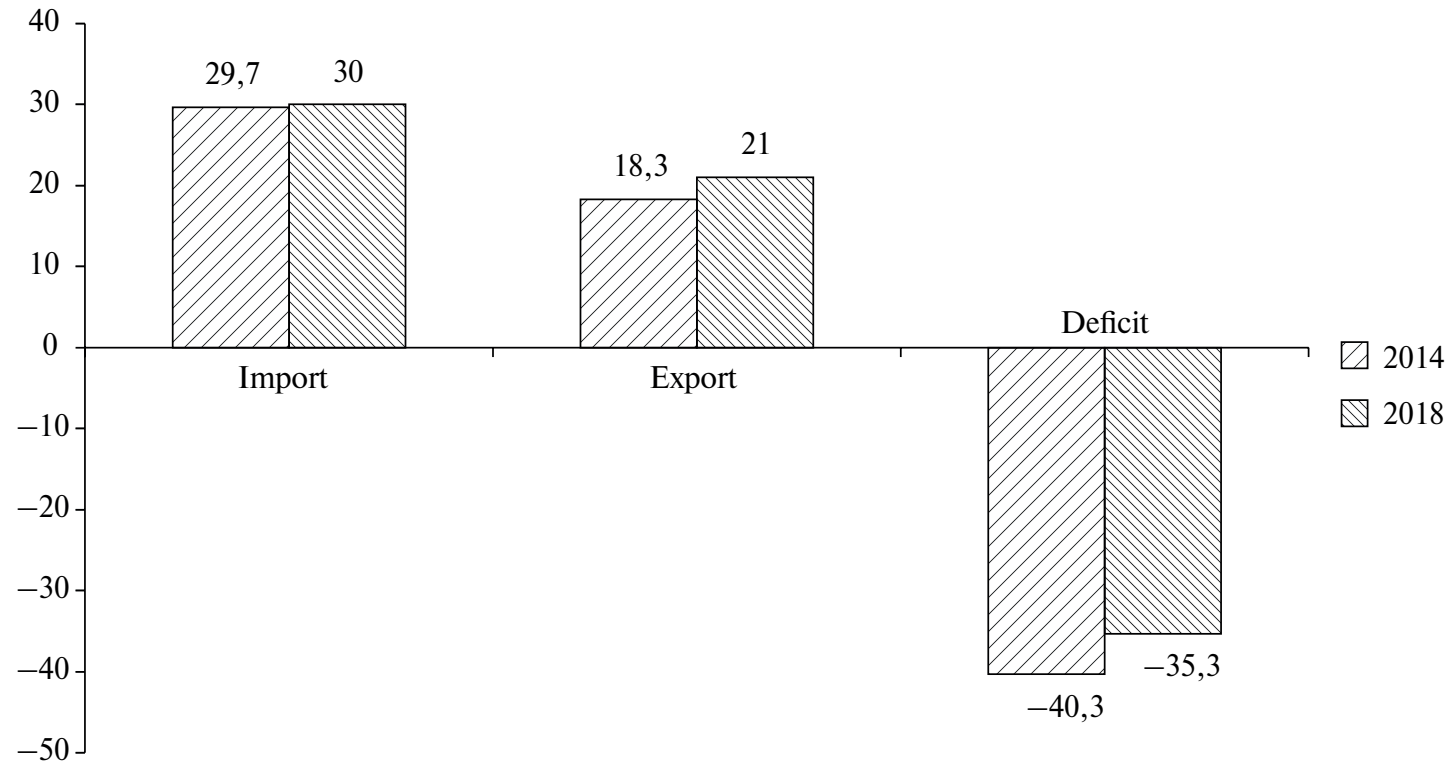

Fig. 8. Indian Shares of Intra RCEP Trade (As of 2014 2018, \%)

Source: [Government of India, n. d.].

However, the import from China increased rapidly from USD 58.2 billion to USD 70.3 billion, while the Indian export to China increased only from USD 13.4 billion to USD 16.8 billion. The trade gap has tremendously grown since China's accession to the World Trade 
Organization (WTO) in 2001. Therefore, it is an important matter of concern for India how the wave of liberalization under the RCEP with further reducing tariff lines would worsen the large size of trade deficit with China. The import of Chinese manufacturing goods and dairy products from New Zealand are the main worry for Indian industries and farmers that resulted in the withdrawal of the RCEP deal [Panda, 2019; Palit, 2019; Sarma, 2020] (see Table 3).

Table 3. Indian Trade with the RCEP Member Nations (As of 2018, USD billion)

\begin{tabular}{|l|c|c|c|}
\hline \multicolumn{1}{|c|}{ Member Nations } & Import & Export & Trade Deficit \\
\hline China & 70.3 & 16.8 & 53.5 \\
\hline ASEAN & 59.3 & 37.5 & 21.8 \\
\hline South Korea & 16.8 & 4.7 & 12.1 \\
\hline Australia & 13.1 & 3.5 & 9.6 \\
\hline Japan & 12.8 & 4.9 & 7.9 \\
\hline New Zealand & 0.6 & 0.4 & 0.2 \\
\hline Total & $\mathbf{1 7 2 . 9}$ & $\mathbf{6 7 . 8}$ & $\mathbf{1 0 5 . 1}$ \\
\hline
\end{tabular}

Source: [Government of India, n. d.].

Last, but not least, a strong domestic political pressure against the RCEP increased that has burdened the Modi government to agree the RCEP deal. In fact, the Indian position on the RCEP deal has been unclear. India changed its position from actively defending why India needed to participate in the RCEP in order not to be isolated in Asia to the decision on withdrawing from the RCEP negotiations in the name of national interests in 2019. In Oct. 2018, the Prime Minister Modi announced that India will not be a part of the RCEP because it does not reflect the basic spirit and guiding principles. After the $3^{\text {rd }}$ ASEAN Summit, the Indian Ministry of External Affairs officially mentioned that the reasons have been conveyed to the RCEP member nations and that the final outcome was not fair and balanced to India [Government of India, 2019].

\section{Risks and Hopes for India after the Withdrawal from the RCEP}

Joining the RCEP would have made India a part of the rule making body to be the largest mega FTA in the world. It could also push India highly needed domestic reforms to make the manufacturing sector more competitive that Modi government targets under name of Make in India. However, the Indian government has faced tremendous political pressures from the various industrial and political organizations to not join the RCEP due to the current economic slowdown estimating the declining economic growth from 6.8 percent in 2019 to 5 percent in 2020 . However, the economic growth declined to minus 10.3 percent in 2020 due to the COVID-19 Pandemic. Therefore, various ministries such as agriculture, steel, chemicals etc. had also opposed the RCEP agreement [Chakraborty, 2019; Panda, 2019; Sarma, 2020; IMF, 2021]

It means that the Indian government without the participation in the RCEP has to take a high risk to lose its opportunity to reform the manufacturing sector and strengthen its trade relationship with other member nations in the long term perspective. India with abundant unskilled labor has a relatively low share of low-skill intensive exports in goods, whereas it has a high share of high-skill intensive exports in goods and services that has been rising continuously. The former declined from about 34 percent in 1995 to 20 percent in 2018, while the latter increased 
from 42 percent to 65 percent during the same period. Therefore, Indian export oriented growth strategy after the withdrawal from the RCEP may face a high risk to weaken its competitiveness particularly in the manufacturing side in the region [Chatterjee, Subramanian, 2020a]

With the declining low-skill and rising high-skill intensive exports since 1995, the trade volume between India and the RCEP member nations increased rapidly. The Indian export with the RCEP member nation rose from USD 48.7 billion in 2010 to USD 67.8 billion in 2018, while the Indian import increased from USD 92.3 billion to USD 172.9 billion during the same period. As a result, the trade deficit grew from USD 43.6 billion to USD 105.1 billion that increased 241 percent within eight years. Therefore, it is no wonder that Indian government and industry fear that Indian participation in the RCEP can enlarge the trade deficit continuously that is also a high risk factor for the national economy in the short term. However, abandoning export orientation seems to get rid of the goose that lays golden eggs. Indeed, the withdrawal from the RCEP would result in constraints on public, corporate and household balance sheets [Government of India, n. d.; Chatterjee, Subramanian, 2020b] (see Table 3, 4).

Table 4. Indian Trade with the RCEP Member Nations (As of 2010, USD billion)

\begin{tabular}{|l|c|c|c|}
\hline \multicolumn{1}{|c|}{ Member Nations } & Export & Import & Trade Deficit \\
\hline ASEAN & 18.1 & 25.8 & 7.7 \\
\hline $\begin{array}{l}\text { Northeast Asia } \\
\text { (China, Japan, Korea) }\end{array}$ & 28.9 & 53.5 & 24.6 \\
\hline $\begin{array}{l}\text { Oceania (Australia, } \\
\text { New Zealand) }\end{array}$ & 1.7 & 13.0 & 11.3 \\
\hline Total & $\mathbf{4 8 . 7}$ & $\mathbf{9 2 . 3}$ & $\mathbf{4 3 . 6}$ \\
\hline
\end{tabular}

Source: [Government of India, n. d.].

Among the opposition groups against the RCEP, Swadeshi Jagrano Manch (SJM) organized a nationwide agitation against the RCEP deal in Oct. 2019. The SJM as an economic group protecting local products and indigenous producers was affiliated with the politically influential Rashtriya Swayamsevak Sangh (RSS) that supported Modi-led political party, BJP in order to win the general elections in 2014 and 2019. Therefore, the agitation against the RCEP organized by the RSS supported groups was one of the strongest signals for the Modi government to withdraw from the RCEP deal.

In addition to the fears of increasing Chinese imports, the dairy industry also played an important role in opposing the RCEP deal. India produces nearly a tenth of global milk production mostly in Modi's home state of Gujarat. The Gujarat Cooperative Milk Marketing Federation (GMMF) attacked on the RCEP deal because it could damage the local small dairy producers. The perception of distrust to the RCEP is a wide set of constituencies gaining greater political supports than opposing highly skilled professionals having little support from political lobbies [Palit, 2019].

As a result, India turns again to inward and hopes that its withdrawal from the RCEP can contribute to revitalizing domestic market and generating economic growth further. Domestic demand is regarded as primacy over export orientation, and trade restrictions increase at the same time. This shift is based on three misconceptions such as a big domestic market size, economic growth based on domestic not export markets, and a de-globalizing trend. However, the domestic market oriented strategy could harm large export opportunities requiring more openness and more global integration [Chatterjee, Subramanian, 2020b]. 


\section{Conclusion}

The RCEP started its negotiations in May 2013. Since then, the 16 RCEP member nations had held their negotiations 28 times and finally agreed all 20 chapters from the trade to the investment-state dispute agreement (ISDA) in the $3^{\text {rd }}$ ASEAN Summit Meeting in Nov. 2019 and signed the RCEP agreement in Nov. 2020 although India did not participate in it.

The RCEP was initiated by ASEAN, China, Japan, and Korea and agreed to start the negotiations based on the ASEAN centrality due to the strong rival between China and Japan in the region. However, in fact, the RCEP started to be led by China because of its overwhelmed economic power in the region that accounted for around 50 percent of the total output in the RCEP, while the Japanese output was about 18 percent of the total output in 2018. Despite the fact, Japan succeeded in including investment and IPR issues in the RCEP negotiations that contributed to increasing the quality and level of the mega FTA. At the same time, the RCEP negotiations led by China weakened the position of ASEAN centrality because its trade dependency on China has increased substantially since the ASEAN+1 FTA in 2001.

The strategic approaches of the three major economies in the RCEP are various for maximizing their national interests. China focuses on responding the repositioning of the U.S. policy in Asia, strengthening its identity as an economic superpower, and promoting its regional leadership in the Asia Pacific region, while Japan pursues to improve its position of negotiations in the TPP, to set agenda in the RCEP, and to check and control Chinese expansion in the region. India's strategies are mainly market expansion, close relation with ASEAN, and increasing connectivity with Northeast Asia and Oceania.

Despite its clear strategic approach to the RCEP, India decided on the withdrawal from the RCEP because of its internal economic and political reasons. India participated in the RCEP negotiations from the beginning and planned to develop its manufacturing industries by accessing to the regional market in the RCEP and the global market based on its trade policy. However, Indian general paranoia on increasing imports from China caused strong fears and spread protectionist movement instead of trade oriented policy direction. The Modi government could not overcome the domestic pressures to protect domestic products and producers although India improved its trade relations and deficit with the RCEP member nations from 2014 to 2018.

The main question is whether the RCEP can be successful without the Indian participation in the RCEP or not. Indian economic share among the 16 RCEP member nations accounted for 9.9 percent in 2018. It is also a large market with nearly 1.4 billion populations. At the same time however, its level of economic development is based on primary industrial sectors so that the market power is limited although it has a high growing potential of domestic market in the future. Overall, the RCEP can function as the largest mega FTA in the world without the Indian participation and it will attract India continuously in the future. By contrary, India will lose her large export opportunities, especially in labor intensive sectors in the region. Additionally, the RCEP has a stronger position than the CPTPP in the Asia Pacific region because of the U.S. withdrawal from the TPP. It will be valid till the Biden government decides on returning to the TPP in the future.

\section{References}

Akimoto D. (2021). Japan Expects Biden to Rejoin the TPP. The Diplomat, 12 February. Available at: https:// thediplomat.com/2021/02/japan-expects-biden-to-rejoin-the-tpp/ (accessed 15 May 2021).

Asian Development Bank (ADB) (2019). Asian Economic Integration Report 2019/2020: Demographic Change, Productivity, and the Role of Technology. Available at: https://dx.doi.org/10.22617/TCS190461-2. 
Association of Southeast Asian Nations (ASEAN) Secretariat (2009). ASEAN Plus Three Cooperation. Available at: https://www.asean.org/wp-content/uploads/2012/06/22206.pdf (accessed 15 May 2021).

Association of Southeast Asian Nations (ASEAN) Secretariat (2012). Guiding Principles and Objectives for Negotiating the Regional Comprehensive Economic Partnership. Available at: https://asean.org/wp-content/ uploads/2012/05/RCEP-Guiding-Principles-public-copy.pdf (accessed 15 May 2021).

Balassa B. (1961). The Theory of Economic Integration. Homewood: Greenwood Press.

Basu Das S. (2017). The Future of Trade Diplomacy. Perspective, no 9. ISEAS-Yusof Ishak Institute. Available at: https://www.iseas.edu.sg/images/pdf/ISEAS_Perspective_2017_9.pdf (accessed 15 May 2021).

Bhagwati J., Panagariya A. (1996). The Theory of Preferential Trade Agreements: Historical Evolution and Current Trends. American Economic Review, vol. 86, no 2, pp. 82-7. Available at: https://www.jstor.org/stable/2118101.

Broda C., Weinstein D.E. (2006). Globalization and the Gains From Variety. The Quarterly Journal of Economics, vol. 121, no 2, pp. 541-85. Available at: https://doi.org/10.1162/qjec.2006.121.2.541.

Chaisse J. (2020). The Regional Comprehensive Economic Partnership's Investment Chapter: One Step Forward, Two Steps Back? Columbia FDI Perspectives no 271, Columbia Center on Sustainable Investment. Available at: https://ccsi.columbia.edu/sites/default/files/content/docs/publications/No-271-Chaisse-FINAL.pdf (accessed 15 May 2021).

Chakraborty S. (2019). Any Agreement on RCEP Deal to Be Based on National Interests - Piyusg Goyal. Business Standard, 12 September. Available at: https://www.business-standard.com/article/economy-policy/ anyagreement-on-rcep-deal-to-be-based-on-national-interests-piyush-goyal-119091200121_1.html (accessed 8 June 2020).

Chatterjee S., Subramanian A. (2020a). India's Export-led Growth: Exemplar and Exception. Working Paper no 1. Ashoka Centre for Economic Policy. Available at: https://ashoka.edu.in/static/doc_uploads/ file_1602585132.pdf (accessed 15 May 2021).

Chatterjee S., Subramanian A. (2020b). India’s Inward (Re)Turn: Is It Warranted? Will It Work? Policy Paper no 1, Ashoka Centre for Economic Policy. Available at: https://www.ashoka.edu.in/static/doc_uploads/ file_1603091486.pdf (accessed 15 May 2021).

Clinton H.R. (2011). America's Pacific Century. Foreign Policy, vol. 189, no 1, pp. 56-63. Available at: https:// foreignpolicy.com/2011/10/11/americas-pacific-century/ (accessed 15 May 2021).

Expertise Asia (2016). TPP Out, RCEP In. 14 November. Available at: http://www.expertise-asia.com/2016/11/ tpp-put-rcep.html (accessed on 8 June 2020).

Government of India (2019). Transcript of Media Briefing by Secretary (East) During PM's Visit to Thailand (November 04, 2019). Ministry of External Affairs, 5 November. Available at: https://www.mea.gov.in/mediabriefings.htm?dtl/32007/Transcript_of_Media_Briefing_by_Secretary_East_during_PMs_visit_to_Thailand_November_04_2019 (accessed 20 June 2020).

Government of India (n. d.). Export Import Data Bank. Ministry of Commerce and Industry. Available at: https://commerce.gov.in/trade-statistics/ (accessed 5 March 2021).

Hamanaka S. (2014). Trans-Pacific Partnership Versus Regional Comprehensive Economic Partnership: Control of Membership and Agenda Setting. ADB Working Paper Series on Regional Economic Integration no 146, Asian Development Bank. Available at: https://www.adb.org/sites/default/files/publication/152753/ reiwp-146.pdf (accessed 13 June 2020).

Hearn A.H., Myers M. (2015). China and the TPP: Asia-Pacific Integration or Disintegration? China and Latin America Report. The Dialogue. Available at: https://www.thedialogue.org/wp-content/uploads/2015/07/ CLA-TPP-Report-final-web.pdf (accessed 15 May 2021).

Hosny A.S. (2013). Theories of Economic Integration: A Survey of the Economic and Political Literature. International Journal of Economy, Management and Social Science, vol. 2, no 5, pp. 133-55. Available at: https:// citeseerx.ist.psu.edu/viewdoc/download?doi=10.1.1.685.3445\&rep=rep1\&type=pdf (accessed 15 May 2021).

International Monetary Fund (IMF) (2021). India. Available at: https://www.imf.org/en/Countries/IND (accessed 19 March 2021). 
Jiang Y. (2010). China's Pursuit of Free Trade Agreements: Is China Exceptional? Review of International Political Economy, vol. 17, no 2, pp. 238-61. Available at: https://doi.org/10.1080/09692290903337799.

Johnston E. (2017). 16 Nation RCEP Talks Resume in Wake of TPP's Demise. Japan Times, 27 February.

Available at: http://www.japantimes.co.jp/news/2017/02/27/business/16-nation-rcep-talks-resume-waketpps-demise/\#.WPWAGSa1v4Y (accessed 8 June 2020).

Joint Expert Group (JEG) for the EAFTA Phase II Study (2009). Desirable and Feasible Option for an East Asia FTA. Available at: https://api.dtn.go.th/files/v3/5e56fd1b6e74072a3c0892b4/download (accessed 15 May 2021).

Kawai M., Wignaraja G. (2008). EAFTA or CEPEA: Which Way Forward? ASEAN Economic Bulletin, vol. 25, no 2, pp. 113-39. Available at: https://www.jstor.org/stable/41220044.

Kimura F., Chen L. (2016). Implications of Mega Free Trade Agreements for Asian Regional Integration and RCEP Negotiation. ERIA Policy Brief no 2016-3, Economic Research Institute for ASEAN and East Asia. Available at: https://www.eria.org/ERIA-PB-2016-03.pdf (accessed 17 March 2021).

Krugman P.R. (1979). Increasing Returns, Monopolistic Competition, and International Trade. Journal of International Economics, vol. 9, no 4, pp. 469-79. Available at: https://doi.org/10.1016/0022-1996(79)90017-5.

Krugman P.R., Obstfeld M. (2009). International Economics: Theory and Policy. Boston: Pearson, AddisonWesley.

Kumar M., Charlton B. (2017). RCEP Will Step Into Gap as Trump Pulls Out of TPP. Oxford Analytica Daily Brief, 23 January. Available at: https://dailybrief.oxan.com/Analysis/DB217448/RCEP-will-step-into-gap-asTrump-pulls-out-of-TPP (accessed 11 June 2020).

La M.Y. (2017). Regional Comprehensive Economic Partnership (RCEP): Progress and Challenges. World Economy Brief, vol. 7, no 12. Available at: https://think-asia.org/bitstream/handle/11540/7212/WEB\%201712.pdf? sequence $=1$ (accessed 15 May 2021).

Molle W. (1990). The Economics of European Integration: Theory, Practice, Policy. Hong Kong, Singapore, Sydney: Brookfield.

Mueller L.M. (2019). ASEAN Centrality Under Threat: The Case of RCEP and Connectivity. Journal of Contemporary East Asia Studies, vol. 8, no 2, pp. 177-98. Available at: https://doi.org/10.1080/24761028.2019.169 1703.

Palit A. (2019). Domestic Politics Force India's Withdrawal From RCEP and Broader Trade Disengagement. Asia Pacific Bulletin no 494, East-West Center. Available at: https://www.eastwestcenter.org/system/tdf/private/apb494.pdf?file $=1 \&$ type $=$ node $\& i d=37358($ accessed 15 May 2021$)$.

Panda J.P. (2014). Factoring the RCEP and the TPP: China, India and the Politics of Regional Integration. Strategic Analysis, vol. 38, no 1, pp. 49-67. Available at: https://doi.org/10.1080/09700161.2014.863462.

Panda R. (2019). A Step Too Far: Why India Opted Out of RCEP. Global Asia, vol. 14, no 4, pp. 82-8. Available at: https://www.globalasia.org/v14no4/feature/a-step-too-far-why-india-opted-out-of-rcep_rajaram-panda (accessed 15 May 2021).

Park S.C. (2018). U.S. Protectionism and Trade Imbalance Between the U.S. and Northeast Asian Countries. International Organisations Research Journal, vol. 13, no 2, pp. 76-100. Available at: https://doi. org/10.17323/1996-7845-2018-02-05.

Park S.C., Pasierbiak P. (2018). Japan's Role in East Asian Economic Regionalism. Institutions and Economies, vol. 10, no 2, pp. 121-45. Available at: https://ijie.um.edu.my/index.php/ijie/article/view/11210/7664 (accessed 15 May 2021).

Ravenhill J. (2016). The Political Economy of an "Asian” Mega FTA. Asian Survey, vol. 55, no 6, pp. 1077100. Available at: https://doi.org/10.1525/AS.2016.56.6.1077.

Sarma N. (2020). Free Trade After RCEP: What Next for India? ORF Issue Brief No 353, Observer Research Foundation. Available at: https://www.orfonline.org/wp-content/uploads/2020/04/ORF_Issue_Brief_353_ RCEP_NEW-08_April.pdf (accessed 15 May 2021). 
Shott J.J. (2017). US Trade Policy Options in the Pacific Basin: Bigger is Better. PIIE Policy Brief, Peterson Institute for International Economics. Available at: https://piie.com/system/files/documents/pb17-7.pdf (accessed 11 June 2020).

Siddique M.A.B. (2007). Regionalism, Trade and Economic Development: Theories and Evidence From the Asia Pacific Region. Regionalism, Trade and Economic Development in the Asia Pacific Region (M.A.B. Siddique (ed.)). Cheltenham: Edward Elgar.

Suh J.K. (2014). Korean Bridge: Balancing Asian Economic Regionalism Between the United States and China. Joint US-Korea Academic Studies, vol. 25, pp. 188-99. Available at: https://keia.org/publication/korean-bridge-balancing-asian-economic-regionalism-between-the-united-states-and-china/ (accessed 16 May 2021).

Terada T. (2013). A Golden Opportunity for Japan's Regional Integration Policy: TPP, RCEP, and CJK. AJISS-Commentary no 173, Nakasone Peace Institute. Available at: http://www.iips.org/en/publications/ data/AJISS-Commentary 173.pdf (accessed 15 May 2021).

The White House (2012). Remarks by National Security Advisor Tom Donilon - As Prepared for Delivery. 15 November. Available at: http://www.whitehouse.gov/the-press-office/2012/11/15/remarks-national-security-advisor-tom-donilon-prepared-delivery (accessed 14 June 2020).

Tinbergen J. (1954). International Economic Integration. Amsterdam: Elsevier.

Urata S. (2013). Constructing and Multilateralizing the Regional Comprehensive Economic Partnership: An Asian Perspective. ADBI Working Paper Series no 449, Asian Development Bank Institute. Available at: https://www.adb.org/sites/default/files/publication/156303/adbi-wp449.pdf (accessed 15 May 2021).

Velut J.-B., Darlingwater L., Boullet V., Peyronel V. (2018). Understanding Mega Free Trade Agreements: The Political and Economic Governance of New Cross-Regionalism. Abingdon: Routledge.

World Bank (2020a). World Bank Data. Available at: https://data.worldbank.org/indicator/NY.GDP.MKTP. KD.ZG?locations=1W (accessed 1 June 2020).

World Bank (2020b). World Bank Open Data. Available at: https://data.worldbank.org/indicator (accessed 8 June 2020).

World Integrated Trade Solution (n. d.). Available at: http://wits.worldbank.org/\# (accessed 9 June 2020).

World Trade Organization (WTO) (2020). Trade Set to Plunge as COVID-19 Pandemic Upends Global Economy. Press Release, 8 April. Available at: https://www.wto.org/english/news_e/pres20_e/pr855_e.htm (accessed 2 June 2020).

Xiao Y. (2015). Competitive Mega-Regional Trade Agreement: Regional Comprehensive Economic Partnership (RCEP) vs. Trans-Pacific Partnership (TPP). CUREJ Electronic Journal, 20 April. Available at: https:// repository.upenn.edu/curej/194/ (accessed 15 May 2021).

Yi Q. (2014). The RCEP: A Chinese Perspective. New Directions in Asia-Pacific Economic Integration (G. Tang, P.A. Petri (eds)). Honolulu: East-West Center. 